\title{
Etika Komunikasi Visual Influencer dalam Promosi Pariwisata
}

\author{
Zakaria L. Sukirno ${ }^{1}$ \\ zakaria@uai.ac.id
}

\begin{abstract}
In tourism promotion, tourist destination visual attraction becomes a weapon to attract attention for tourism influencers through their social media. But visual ethical problem appears when photograph has been edited or manipulated by them. Thus, "what does visual communication ethic from influencer in tourism promotion like?". This research based on concepts of utilitarian ethics, visual communication ethics, and tourism visual communication. For its methodology, this research uses positivistic paradigm, descriptive research, and utilitarian ethical evaluation method. Research findings obtained the quantification of harmful consequences and good consequences for tourism influencers photograph manipulation, and two alternative acts for tourism influencers visual communication ethics.
\end{abstract}

Keywords: Tourism influencer, Visual communication, Utilitarian ethics, Visual communication ethics

\begin{abstract}
Abstrak
Dalam promosi pariwisata, atraktivitas visual destinasi wisata menjadi senjata penarik perhatian bagi para influencer pariwisata melalui media sosialnya. Akan tetapi permasalahan etika secara visual juga terjadi ketika foto yang telah diedit atau dimanipulasi oleh para influencer pariwisata. Maka, "seperti apa etika komunikasi visual dari influencer dalam promosi pariwisata?" Penelitian ini berbasis pada konsep etika utilitarian, etika komunikasi visual, dan komunikasi visual pariwisata. Untuk metodologi, penelitian ini menggunakan paradigma positivistik, riset deskriptif, dan metode evaluasi etika utilitarian. Temuan riset yang didapatkan adalah kuantifikasi konsekuensi buruk dan konsekuensi baik untuk manipulasi foto influencer pariwisata, serta dua tindakan alternatif etika komunikasi visual influencer pariwisata.
\end{abstract}

Kata kunci: Influencer pariwisata, Komunikasi visual, Etika utilitarian, Etika komunikasi visual

1 Dosen pada Program Studi Ilmu Komunikasi FISIP Universitas Al Azhar Indonesia. Peserta Program Doktor Ilmu Komunikasi FISIP UI 


\section{Pendahuluan}

Imaji merupakan berkah bagi indera pengelihatan kita. Kita dapat melihat representasi realita ataupun simulasi dari imaji yang terpampang di media. Iklan, film, foto dan video jurnalistik, kartun, komik, dan sebagainya dapat kita konsumsi dalam lanskap media sehari - hari. Iklan menampilkan produk, tokoh, atau organisasi yang dipromosikan secara visual. Foto dan video jurnalistik menjadi medium akan informasi berita di koran, majalah, dan televisi. Film, komik, dan kartun merupakan representasi visual dari imajinasi kreatif yang memiliki fungsi hiburan. Imaji - imaji yang direpresentasikan melalui media - media tersebut merupakan bentuk dari komunikasi visual.

Komunikasi visual merupakan bentuk yang biasa digunakan dalam promosi pariwisata. Tampilan visual keindahan destinasi wisata, fasilitas destinasi wisata, serta industri pendukung pariwisata seperti hotel dan transportasi menjadi atraksi visual yang bertujuan menggugah afeksi calon wisatawan untuk melakukan pemesanan value pariwisata yang dideskripsikan. Inovasi dan dinamika media digital semakin memungkinkan penetrasi komunikasi pemasaran pariwisata masuk ke ranah pribadi pengguna internet - yang biasa disebut sebagai user.

Atraktivitas visual destinasi wisata inilah yang menjadi senjata penarik perhatian bagi para influencer pariwisata. Melalui media sosialnya, mereka kerap memposting foto - foto indahnya panorama alam, betapa baiknya fasilitas wisata, atau keunggulan destinasi yang ditampilkan. Influencer pariwisata juga menambahkan teks persuasif dalam postingan foto sebagai komunikasi visual untuk menambah ketertarikan para user yang menjadi follower atau subscriber mereka.

Akan tetapi senyampang berlimpahnya bentuk komunikasi pemasaran visual di media digital, permasalahan etika secara visual juga kerap terjadi. Paparan imaji yang tidak etis hadir sebagai stimulus bagi indera pengelihatan. Foto yang telah diedit atau dimanipulasi oleh para influencer pariwisata sehingga menghiperboliskan realita atau naturalitas destinasi dan industri pendukung pariwisata semakin mudah dijumpai di layar komputer dan smartphone. Melalui situs dan media sosial, strategi kreatif promosi visual dari influencer semacam itu merupakan upaya persuasif pemasar pariwisata supaya user tertarik perhatiannya, menyukai, memutuskan, dan melakukan pemesanan value pariwisata yang dipromosikan. Dampaknya yang pertama adalah bagi user sebagai konsumen/pelanggan pariwisata menjadi korban, khususnya jika tampilan visual promosi pariwisata yang sangat jauh sekali berbeda dari realita destinasi wisata dan sarananya. Yang kedua adalah bagi pemasaran pariwisata itu sendiri karena ketidakpuasan turis dan negative sentiment share yang akan menurunkan bisnis pariwisata itu sendiri.

Satu kasus viral dan dilaporkan oleh beberapa media jurnalistik yaitu cerita Polina Marinova, editor majalah Fortune ketika berwisata ke Pura Lempuyangan di Karangasem, Bali. Polina membagikan curahan hati kekecewaannya di Twitter karena postingan Instagram influencer yang menampilkan indahnya foto Pura Lempuyangan dengan refleksi pura dan langit indahnya di air namun realitanya tidaklah demikian. 
Dalam kasus Polina ini kita bisa melihat bagaimana dia menjadi korban simulasi/ simulacrum dan hiperrealisme dalam estetika seni seperti apa yang disampaikan oleh Jean Baudrillard. Baudrillard dalam Harrison dan Wood menyatakan bahwa hiperrealisme merupakan pengulangan duplikasi yang sangat teliti dari realitas sesungguhnya menggunakan media reproduktif namun menjadi berubah dari realitanya itu sendiri, hancur karena sudah bukan menjadi objek representasi realitanya (1999 : 1049). Objek realita dan imajiner dapat digabungkan melalui operasional daya tarik estetika yang melibatkan pemalsuan, montase, skenario, dan penyajian yang berlebihan akan realita (1999 : 1051).

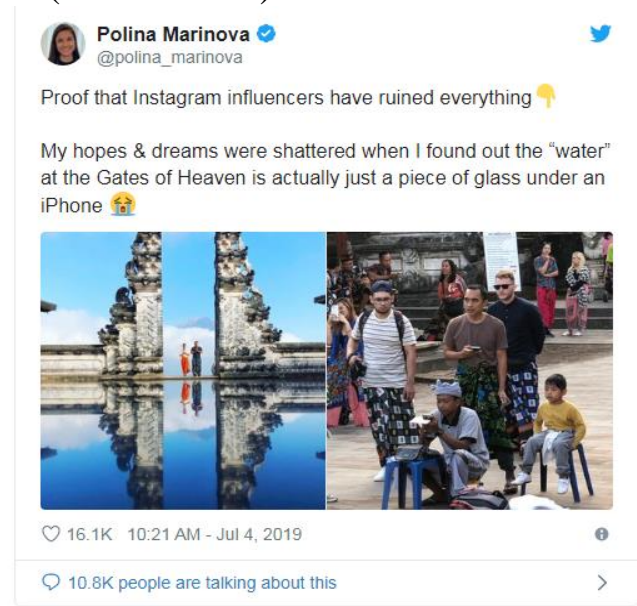

Unggahan tersebut lantas disukai lebih dari 14.000 kali, dan di retweet 9.3000 kali.

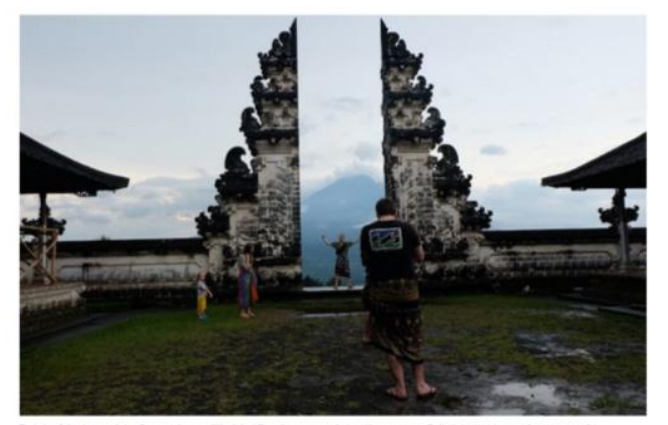

(Sumber

https://travel.kompas.com/read/2019/07/10/190151427/vir al-turis-asing-kecewa-saat-berburu-foto-pura-lempuyangbali.)

\begin{abstract}
Apa yang dilakukan oleh influencer pariwisata dalam memanipulasi foto destinasi wisata sebagai bentuk komunikasi visual adalah yang disebut sebagai simulacrum. Simulacrum terjadi melalui fase imaji. Baudrillard, dalam Poster menjelaskan fase imaji tersebut sebagai berikut:
\end{abstract}

\section{Fase Imaji}

1. Imaji menjadi refleksi akan realita.

2. Imaji menutupi dan menyelewengkan realita.

3. Imaji menutupi ketidakhadiran realita.

4. Imaji tidak memiliki relasi dengan realita apapun, tetapi murni menjadi simulacrum.

Dari kasus foto influencer pariwisata tentang Pura Lempuyangan, maka foto tersebut merupakan bentuk simulacrum karena sudah mengalami penyelewengan realita, menutupi ketiadaan tanah dalam pura dengan manipulasi refleksi air, dan pada akhirnya tidak memiliki relasi dengan realita Pura Lempuyangan sesungguhnya. Ketika Polina Marinova mempercayai simulacrum Pura Lempuyangan dengan refleksi air, maka kondisi itu disebut sebagai hiperrealita.

Dinamika teknologi komunikasi dan informasi (ICT) dengan inovasi internet untuk publik, inovasi fotografi digital, dan bentuk revolusi digital lainnya berimplikasi terhadap tren komunikasi visual dan komunikasi pemasaran pariwisata. Pada era fotografi analog, proses imaging dilakukan secara terpisah berdasarkan divisi keahlian fotografi seperti proses pemotretan, proses cuci film, dan manipulasi foto serta cetak foto. Pada era digital saat ini, setelah proses pemotretan, seseorang bisa melakukan 
proses manipulasi atau foto editing secara digital (atau disebut juga digital imaging) melalui komputernya, kemudian karya fotografinya bisa berbentuk cetak dengan printer personal atau di-posting ke dalam website dan media sosialnya. Konvergensi fotografi dengan mobile communication dalam bentuk smartphone secara drastis telah mengubah perilaku fotografi. Kamera bertransformasi dalam bentuk smartphone, termasuk perangkat digital imaging-nya berkembang dalam bentuk photo editor apps.

Kemampuan teknologi digital dalam manipulasi fotografi sebagai salah satu bentuk komunikasi visual tersebut menjadi potensi masalah etika komunikasi. Pariwisata sebagai salah satu industri dan bisnis jasa yang kerap memanfaatkan karya fotografi sebagai bentuk promosinya akhirnya juga terkait dengan masalah etika tersebut. Kasus Polina Marinova membuktikan adanya pelanggaran etika komunikasi visual.

Berbeda dengan fotografi dalam industri komunikasi seperti fotografi komersial, fotografi jurnalistik, dan fotografi dalam komunikasi pemasaran yang telah memiliki kode etik profesi, karya foto influencer social media sebagai bentuk komunikasi visual belum memiliki standar etika.

Riset dan artikel ilmiah terdahulu seputar etika komunikasi visual pariwisata antara lain:

\begin{tabular}{|c|l|l|}
\hline No & \multicolumn{1}{|c|}{ Tulisan } & \multicolumn{1}{|c|}{ Jurnal } \\
\hline 1 & $\begin{array}{l}\text { Caroline Scarles. (2013). The Ethics of } \\
\text { Tourist Photography: Tourists' Experiences } \\
\text { of Photographing Locals in Peru. }\end{array}$ & $\begin{array}{l}\text { Sage Journal. Environment } \\
\text { and Planning D : Society and } \\
\text { Space. Volume: 31 issue: 5, } \\
\text { page(s): 897-917 }\end{array}$ \\
\hline 2 & $\begin{array}{l}\text { Jeanette Mcdonald. (2016). The Role of } \\
\text { Ethics on Tourist Destination Image } \\
\text { Formation : An Analysis of } \\
\text { the French Student Travel Market }\end{array}$ & $\begin{array}{l}\text { HAL Id: tel-01250976 } \\
\text { https://tel.archives- } \\
\text { ouvertes.fr/tel-01250976 } \\
\text { Submitted on 5an 2016 }\end{array}$ \\
\hline 3 & $\begin{array}{l}\text { Adriana Campelo, Robert Aitken and Juergen } \\
\text { Gnoth. (2010). Visual Rhetoric and Ethics in } \\
\text { Marketing of Destinations. }\end{array}$ & $\begin{array}{l}\text { Journal of Travel Research } \\
\text { published online 19 March } \\
\text { 2010. } \\
10.1177 / 0047287510362777\end{array}$ \\
\hline
\end{tabular}

\section{Perumusan Masalah}

"Seperti apa etika komunikasi visual influencer dalam promosi pariwisata?"

\section{Kerangka Konseptual}

\section{Komunikasi Visual}

Martin Lester memberikan definisi komunikasi visual sebagai segala bentuk pesan yang merangsang/menstimulasi indera penglihatan yang dipahami oleh orang yang menyaksikannya (2006 : 424). Harry Jamieson mendefinisikan komunikasi visual sebagai seni visual (visual arts) yang terpampang di berbagai media dengan menampilkan imaji visual (visual images). Dalam ranah bisnis, imaji bertujuan untuk memberikan kenikmatan (pleasure) dan mempunyai kekuatan untuk memberikan informasi (2007: 10). 
Sedangkan David Machin menjelaskan bahwa komunikasi visual adalah representasi dari penggunaan serangkaian sumber daya visual untuk mengkomunikasikan gagasan, sikap, dan nilai - nilai serta bentuk atau makna kebudayaan kepada pihak lain (2014: 30).

\section{Prinsip Etika Utilitarian}

Christian dalam Cheney, May, Munshi menuliskan penjelasan tentang etika utilitarian. Jeremy Bentham menyatakan bahwa keputusan moral terbaik adalah yang mampu meningkatkan jumlah kebahagiaan terbanyak dan meminimalkan luka (where morally acceptable decisions promote the greatest amount of happiness and minimized harm). John Stuart Mill mengamini dan menambahkan gagasan Bentham dengan ide keseimbangan terbaik adalah yang baik bagi kesemuanya. Mill mengungkapkan bahwa tindakan itu benar dalam proporsi jika cenderung meningkatkan kebahagiaan; salah jika cenderung memproduksi lawan dari kebahagiaan (Actions are right in proportion as they tend to promote happiness; wrong as they tend to produce the reverse of happiness) (2011: 191).

Straubhaar, Larose, dan Davenport menjelaskan bahwa prinsip utilitarian John Stuart Mill menyatakan bahwa kita harus mencari kebahagiaan terbesar untuk jumlah terbesar. Mill berpendapat bahwa apa yang akan membawa kebaikan terbesar bagi masyarakat, dia definisikan sebagai menguntungkan orang dalam jumlah besar. Dalam hal ini kita mempertimbangkan potensi manfaat dan kerugian, menentukan yang mana tindakan akan menguntungkan kebanyakan orang atau merugikan paling sedikit akan tindakan yang kita pilih (2012 : 475). Sedangkan Rodman menuliskan prinsip etika utilitarian adalah gagasan bahwasanya tindakan disebut etis hanya jika hasil dari tindakan tersebut sangat baik bagi banyak orang (2012: 438).

\section{Etika Komunikasi Visual}

Biagi mengatakan bahwa etika berasal dari Yunani yaitu ethos yang artinya bantuan moral atau tradisi yang mengatur sebuah budaya. Etika adalah peraturan atau standar yang mengatur perilaku seseorang. Secara professional, etika atalah peraturan, standar yang mengatur perilaku profesi anggotanya (Biagi, 2010 : 418).

Julianne H. Newton dalam Smith, Moriarty, Barbatsis, Kenney, mengungkapkan bahwa etika visual berkenaan dengan apa yang benar dan apa yang salah dalam penggunaan imaji. Lebih detail lagi Newton mendefinisikan etika visual sebagai studi tentang bagaimana imaji mempengaruhi cara pikir, rasa, perilaku, serta kreasi, penggunaan, dan interpretasi makna imaji yang benar dan yang salah (2005 : 433).

Sean Cubitt dan Violeta Politoff dalam Cheney, May, Munshi, menyebutkan bahwa teknologi digital atau new media membawa dampak terhadap etika komunikasi visual. Imaji menjadi lebih cepat, lebih murah, dan lebih mudah untuk diedit. Kemampuan teknologi digital memiliki kekuatan untuk menyelewengkan produksi imaji, digunakan secara salah untuk tujuan hiburan. Imaji menjadi termanipulasi dan tidak lagi dapat dipercaya (2011 : 251). Fahmy, Bock, Wanta mengkritisi munculnya fotografi digital dan photo editing software, terjadi peningkatan nyata dalam 
kemampuan untuk memanipulasi dan kemampuan untuk melakukannya tanpa terlihat melakukannya. Dengan kata lain, fotografi digital menjadi lebih mudah untuk berbohong dengan meyakinkan. Penggunaan teknologi digital ini mengangkat inti pertanyaan etis tentang kebenaran dan potensi hilangnya kepercayaan publik terhadap media visual (2014 : 95).

\section{Komunikasi Visual Pariwisata}

Machin menjelaskan bahwa komunikasi visual dalam pariwisata dikaitkan dengan hal mendasar bagaimana fenomena pariwisata dengan dinamika realitas sosialnya dijelaskan melalui representasi visual. Pariwisata sebagai pertukaran komersial dan lintas budaya dikombinasikan dengan dampak ekonominya membuat komunikasi dalam bentuk apa pun secara simultan menjadi sangat penting. Riset pasar dalam pemasaran pariwisata berfokus pada upaya menggambarkan bahasa pariwisata dengan menggunakan representasi visual. Promosi pariwisata dianggap sebagai produk yang diinginkan pemasar dengan tujuan untuk memanfaatkan dan mengarahkan pandangan turis ke arah value pariwisata dan pengalaman pariwisata. Pariwisata digambarkan sebagai bagian dari industri tontonan (spectacle industry). Foto sebagai bentuk komunikasi visual atau media komunikasi visual, menjadi hal penting dalam realita pariwisata. Kemampuan fotografi yang detail dapat menghadirkan realita dan deskripsi sesungguhnya akan destinasi wisata ( $2014: 741$ ).

Machin menunjukkan kritik akan manipulasi foto yang memunculkan permasalahan ketika foto atau imaji tidak secara akurat merepresentasikan fitur materi destinasi wisata atau bahkan menipu (deceptive) sehingga menimbulkan makna konotatif yang berbeda dari realita destinasi wisata tersebut. Dalam hal promosi yang negatif, foto menjadi masalah karena penggambaran secara intensional yang berlebihan dari kehidupan sesungguhnya. Sehingga foto sebagai komunikasi pemasaran visual pariwisata menjadi misrepresentasi, bukan representasi lagi (2014 : 742).

\section{Influencer}

Paul Copley mendefinisikan influencer adalah sebagai orang yang secara formal atau informal mampu mendorong penjualan (2004: 68). Atau, menurut Brown dan Hayes, influencer merupakan individu individu yang mampu menyarankan ke arah pembelian dari sudut pandang konsumen (2008 : xii). Sedangkan Cakim menuliskan bahwa dalam dunia pemasaran online, online influencer adalah orang - orang yang dicari dan diikuti sarannya oleh pengikut (followers) dalam media milik konsumen (consumer generated media) (2010 : 23).

\section{Metodologi Penelitian}

\section{Paradigma Penelitian}

Paradigma penelitian yang dipilih dalam penelitian ini adalah paradigma positivistik. Neuman menjelaskan bahwa paradigma positivistik adalah pendekatan riset sosial yang menekankan pada penemuan kausal, observasi empiris, dan bebas nilai (2006 : 81). Penelitian positivistik merupakan organisasi metode yang mengkombinasikan logika deduktif dengan observasi empiris untuk menemukan dan mengkonfirmasi suatu rangkaian probabilitas kausal yang dapat 
digunakan untuk memprediksi aktivitas manusia secara umum (2006: 82).

\section{Sifat Penelitian}

Sifat penelitian ini adalah deskriptif. Menurut Neuman, penelitian deskriptif bertujuan untuk menghadirkan gambaran spesifik dari suatu situasi, latar, atau hubungan sosial. Penelitian deskriptif berfokus pada 'how' dan 'who' dalam menggambarkan suatu isu atau kejadian (Neuman, 2006 : 35).

\section{Metode Analisis Data}

Teknik analisis data yang digunakan adalah metode evaluasi etika utilitarian. Joseph Dominick menjelaskan bahwa metode evaluasi etika utilitarian menganalisis pilihan pilihan tindakan dengan langkah:

1. Mengkalkulasi semua konsekuensi baik dan buruk yang akan muncul dari masing masing pilihan tindakan.

2. Memilih alternatif tindakan yang akan memaksimalkan nilai manfaat dan meminimalkan kerugian (2013: 411).

\section{Analisis dan Interpretasi Data}

Analisis yang pertama dilakukan terhadap konsekuensi buruk jika tindakan manipulasi foto dilakukan oleh influencer pariwisata. Berikut tabel analisis utilitarian terhadap konsekuensi buruk:

\begin{tabular}{|c|c|c|}
\hline Pihak & $\begin{array}{c}\text { Konsekuensi Buruk Jika Influencer Memanipulasi } \\
\text { Komunikasi Visual Destinasi Pariwisata }\end{array}$ & $\begin{array}{l}\text { Kuantifikasi } \\
\text { Konsekuensi }\end{array}$ \\
\hline Destinasi wisata & $\begin{array}{l}\text { - Review negatif } \\
\text { - Penurunan tingkat kunjungan } \\
\text { - Penurunan pendapatan } \\
\text { - } \quad \text { Penurunan citra }\end{array}$ & -4 \\
\hline Akomodasi & $\begin{array}{l}\text { Penurunan pemesanan } \\
\text { - } \quad \text { Penurunan stay rate } \\
\text { - } \quad \text { Penurunan pendapatan } \\
\end{array}$ & -3 \\
\hline Transportasi & $\begin{array}{l}\text { - Penurunan pemesanan pemberangkatan } \\
\text { - Penurunan pemesanan pulang } \\
\text { - Penurunan pendapatan }\end{array}$ & -3 \\
\hline Influencer & $\begin{array}{l}\text { - } \quad \text { Negative comments } \\
\text { - Hilangnya kredibilitas } \\
\text { - Penurunan tingkat kepercayaan } \\
\text { - Penurunan subscriber/follower }\end{array}$ & -4 \\
\hline Wisatawan & $\begin{array}{ll}\text { - } & \text { Ketidakpuasan } \\
\text { - } & \text { Kerugian pengeluaran transportasi pergi } \\
\text { - } & \text { Kerugian pengeluaran transportasi pulang } \\
\text { - } & \text { Kerugian pengeluaran akomodasi } \\
\text { - } & \text { Kerugian pemanfaatan waktu }\end{array}$ & -5 \\
\hline
\end{tabular}

Analisis yang kedua dilakukan terhadap konsekuensi baik jika tindakan manipulasi foto tidak dilakukan oleh influencer pariwisata.
Berikut tabel analisis utilitarian terhadap konsekuensi baik: 


\begin{tabular}{|c|c|c|}
\hline Pihak & $\begin{array}{c}\text { Konsekuensi Baik Jika Influencer Tidak Memanipulasi } \\
\text { Komunikasi Visual Destinasi Pariwisata }\end{array}$ & $\begin{array}{l}\text { Kuantifikasi } \\
\text { Konsekuensi }\end{array}$ \\
\hline $\begin{array}{l}\text { Destinasi } \\
\text { wisata }\end{array}$ & $\begin{array}{l}\text { - Review positif/netral } \\
\text { - Peningkatan kunjungan } \\
\text { - Peningkatan pendapatan } \\
\text { - Peningkatan popularitas } \\
\text { - Potensi revisit } \\
\end{array}$ & 5 \\
\hline Akomodasi & $\begin{array}{l}\text { - Peningkatan pemesanan } \\
\text { - Peningkatan stay rate } \\
\text { - Peningkatan pendapatan } \\
\text { - } \quad \text { Potensi revisit } \\
\end{array}$ & 4 \\
\hline Transportasi & $\begin{array}{l}\text { - } \quad \text { Peningkatan pemesanan pergi } \\
\text { - } \quad \text { Peningkatan pemesanan pulang } \\
\text { - } \quad \text { Potensi pemesanan ulang masa depan } \\
\end{array}$ & 3 \\
\hline Influencer & $\begin{array}{l}\text { - Peningkatan kepercayaan } \\
\text { - Positive comments } \\
\text { - Peningkatan kredibilitas } \\
\text { - Peningkatan Key Opinion Leader (KOL) metrics } \\
\text { - Potensi peningkatan endorsement }\end{array}$ & 5 \\
\hline Wisatawan & $\begin{array}{l}\text { - Kepuasan berwisata } \\
\text { - Peningkatan aktualisasi diri atas pengalaman } \\
\text { wisata }\end{array}$ & 2 \\
\hline
\end{tabular}

Berdasarkan analisis utilitarian tersebut, maka perlu dilakukannya tindakan etis oleh influencer pariwisata untuk tidak melakukan manipulasi terhadap bentuk komunikasi visual akan destinasi wisata yang dipromosikannya. Maka secara objektif, sangatlah penting untuk menetapkan suatu ketentuan etis bagi influencer pariwisata untuk tidak melakukan manipulasi komunikasi visual karena menghasilkan dampak yang besar dalam industri pariwisata. Dengan demikian, perlu penetapan atau pemberlakuan larangan manipulasi komunikasi visual sebagai suatu premis dalam kode etik komunikasi visual bagi influencer pariwisata.

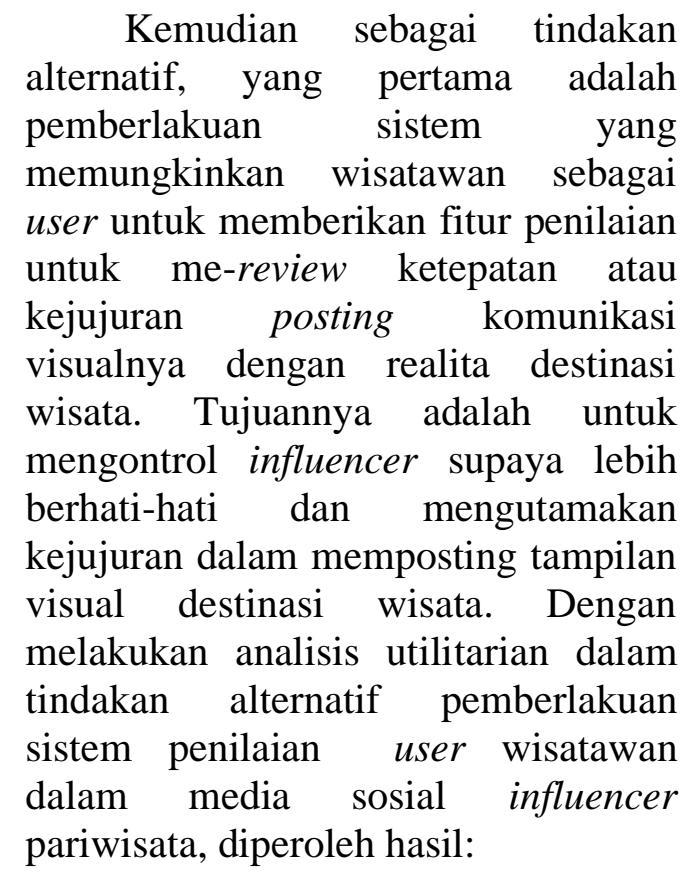




\begin{tabular}{|c|c|c|}
\hline Pihak & $\begin{array}{c}\text { Sistem Penilaian User untuk Visual Influencer Pariwisata } \\
\text { dalam Media Sosial }\end{array}$ & $\begin{array}{l}\text { Kuantifikasi } \\
\text { Konsekuensi }\end{array}$ \\
\hline Influencer & 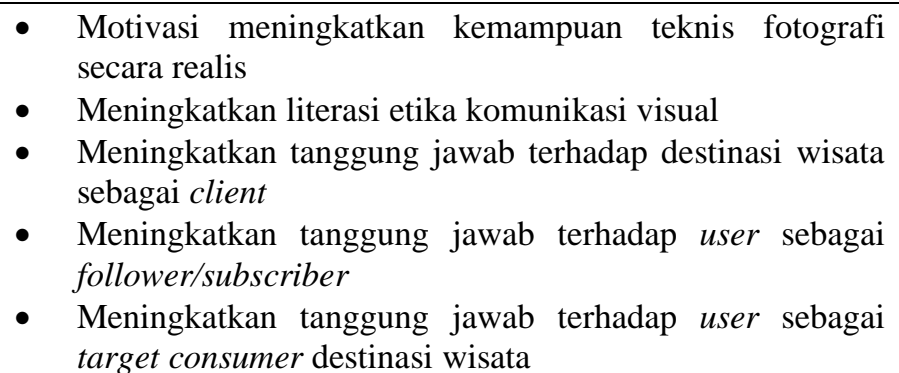 & 5 \\
\hline Destinasi wisata & $\begin{array}{l}\text { - Review positif/netral } \\
\text { - Peningkatan tingkat kepercayaan terhadap destinasi } \\
\text { karena penerapan etika komununikasi visual } \\
\text { pariwisatanya melalui influencer }\end{array}$ & 2 \\
\hline Wisatawan & $\begin{array}{l}\text { - Pemberdayaan sikap kritis user } \\
\text { - Sebagai aktor mekanisme kontrol terhadap influencer } \\
\text { pariwisata }\end{array}$ & 2 \\
\hline
\end{tabular}

Alternatif kedua adalah publikasi dari media jurnalistik atau media berita tentang ranking dan rating kredibilitas influencer pariwisata dengan menggunakan kesesuaian posting komunikasi visual dari infuencer dengan realita destinasi wisata. Publikasi ini memiliki manfaat literasi bagi user yang akan melakukan perjalanan wisata serta bagi pebisnis pariwisata dalam menganalisis kualitas influencer pariwisata. Dengan melakukan analisis utilitarian dalam tindakan alternatif publikasi media tentang ranking dan rating kredibilitas influencer pariwisata dengan menggunakan tingkat kesesuaian posting komunikasi visual dengan realita destinasi wisata, diperoleh hasil analisis sebagai berikut:

\begin{tabular}{|l|l|c|}
\hline \multicolumn{1}{|c|}{ Pihak } & $\begin{array}{c}\text { Publikasi Ranking/Rating Influencer Pariwisata dengan } \\
\text { Indikator Kesesuaian Posting Komunikasi Visual dengan } \\
\text { Realita Destinasi Wisata oleh Media Berita }\end{array}$ & $\begin{array}{c}\text { Kuantifikasi } \\
\text { Konsekuensi }\end{array}$ \\
\hline Influencer & $\begin{array}{l}\text { Motivasi untuk tidak memanipulasi foto destinasi } \\
\text { wisata. }\end{array}$ & 3 \\
\hline Destinasi wisata & $\begin{array}{l}\text { Motivasi untuk meningkatkan kredibilitas profil. } \\
\text { - Motivasi untuk bertindak objektif }\end{array}$ & 2 \\
\hline Wisatawan & $\begin{array}{l}\text { Sebagai informasi untuk seleksi influencer potensial } \\
\text { Membantu SWOT perencanaan promosi pariwisata }\end{array}$ & 2 \\
\hline
\end{tabular}

\section{Keterbatasan Penelitian}

1. Berdasarkan hasil analisis, wisatawan sebagai konsumen menjadi objek marginal sebab memiliki angka konsekuensi buruk tertinggi namun mendapatkan konsekuensi baik terendah.
2. Klikauer mengkritisi prinsip etika utilitarian sebagai mode penilaian kapitalis (2008 : 288). Dalam hasil analisis tampak bahwa industri pariwisata dan influencer sebagai pihak yang memiliki kapital memperoleh angka konsekuensi 
baik yang lebih tinggi karena lebih berpotensi mendapatkan manfaat.

3. Neuman mengkritisi paradigma positivisme sebagai paradigma penelitian sosial yang digunakan memiliki kelemahan yaitu menganggap individu atau pelaku sosial sebagai mechanical model of man (2006 : 83). Dalam riset ini, manusia atau individu, dan institusi atau organisasi dinilai secara numerik.

\section{Daftar Pustaka}

Agmasari, Silvita. (2019). "Viral, Turis Asing Kecewa saat Berburu Foto Pura Lempuyang Bali".

Kompas.com. https://travel.kom pas.com/read/2019/07/10/19015 1427/viral-turis-asing-kecewasaat-berburu-foto-puralempuyang-bali. Diakses pada October, 16, 2019, 18.51

Baudrillard, Jean. (1983). Simulacra and Simulations, (terj.) Paul Foss, Paul Patton and Philip Beitchman, dalam Poster, Mark. Jean Baudrillard : Selective Writings. New York: Semiotext(e).

Biagi, Shirley. Media/Impact: Pengantar Media Massa, ed 9 (terj. Mochammad Irfan dan Wulung Wira Mahendra). Jakarta: Salemba Humanika

Brown, Duncan, Nick Hayes. (2008). Influencer Marketing : Who Really Influences Your Customers?. Oxford : Elsevier

Cakim, Idil Mariam. (2010). Implementing Word of Mouth Marketing : Online Strategies to Identify Influencers, Craft
Stories, and Draw Customers. New Jersey: Wiley

Cheney, George, Steve May, Debashish Munshi. (2011). The Handbook of Communication Ethics. New York: Routledge

Copley, Paul. (2004). Marketing Communications Management : Concepts and Theories, Cases and Practices. Oxford : Elsevier

Dominick, Joseph R. (2013). The Dynamics of Mas Communication, $12^{\text {th }} \mathrm{ed}$. New York : McGraw-Hill

Fahmy, Shahira, Mary Angela Bock, Wayne Wanta. (2014). Visual Communication Theory And Research : A Mass Communication Perspective. New York : Palgrave Macmillan

Harrison, Charles, Paul Wood. (1999). Art in Theory, 1900-1990 : An Anthology of Changing Ideas. Oxford : Blackwell.

Jamieson, Harry. (2007). Visual Communication : More Than Meets the Eye. Bristol : Intellect

Klikauer, Thomas. (2008). Management Communication : Communicative Ethics and Action. New York : Palgrave Macmillan

Lester, Martin. (2006). Visual Communication - Images with Message. Belmont : Thomson Wadsworth.

Machin, Daniel. (2014). Visual Communication. Berlin/Boston : De Gruyter Mouton

Neuman, W. Lawrence. (2006). Social Research Methods : Qualitative 
and Quantitative Approaches, $6^{\text {th }}$ ed. Boston : Pearson

Rodman, George. (2012). Mass Media in A Changing World : History, Industry, Controversy, $4^{\text {th }} \mathrm{ed}$. New York : McGraw-Hill

Smith, Ken, Sandra Moriarty, Gretchen Barbatsis, Keith Kenney. (2005). Handbook of Visual Communication Research : Theory, Methods, and Media. Mahwah : Lawrence Erlbaum Associates

Straubhaar, Joseph, Robert Larose, Lucinda Davenport. (2012). Media Now : Understanding Media, Culture, and Technology, $7^{\text {th }}$ Ed. Boston : Wadsworth 
